\title{
Regulation of Antibody Titer Process
}

National Cancer Institute

\section{Source}

National Cancer Institute. Regulation of Antibody Titer Process. NCI Thesaurus. Code C40583.

Any physiologic response that results in an increased number of active antibodies circulating in the plasma. This process is involved in tuning the antibody response to recently exposed antigens. 